Research Paper

\title{
Secretion of laccase and manganese peroxidase by Pleurotus strains cultivate in solid-state using Pinus spp. sawdust
}

\author{
Marli Camassola, Letícia O. da Rosa, Raquel Calloni, Tamara A. Gaio, Aldo J.P. Dillon \\ Instituto de Biotecnologia, Universidade de Caxias do Sul, Caxias do Sul, RS, Brazil.
}

Submitted: May 14, 2011; Approved: July 2, 2012.

\begin{abstract}
Pleurotus species secrete phenol oxidase enzymes: laccase (Lcc) and manganese peroxidase (MnP). New genotypes of these species show potential to be used in processes aiming at the degradation of phenolic compounds, polycyclic aromatic hydrocarbons and dyes. Hence, a screening of some strains of Pleurotus towards Lcc and MnP production was performed in this work. Ten strains were grown through solid-state fermentation on a medium based on Pinus spp. sawdust, wheat bran and calcium carbonate. High Lcc and $\mathrm{MnP}$ activities were found with these strains. Highest Lcc activity, $741 \pm 245 \mathrm{U} \mathrm{gdm}^{-1}$ of solid state-cultivation medium, was detected on strain IB1 1 after 32 days, while the highest MnP activity occurred with strains IB05, IB09, and IB11 (5,333 $\pm 357 ; 4,701 \pm 652$; $5,999 \pm 1,078 \mathrm{U} \mathrm{gdm}^{-1}$, respectively). The results obtained here highlight the importance of further experiments with lignocellulolytic enzymes present in different strains of Pleurotus species. Such results also indicate the possibility of selecting more valuable strains for future biotechnological applications, in soil bioremediation and biological biomass pre-treatment in biofuels production, for instance, as well as obtaining value-added products from mushrooms, like phenol oxidase enzymes.
\end{abstract}

Key words: Pleurotus, laccase, manganese peroxidase, mushroom production, biotechnological applications.

\section{Introduction}

Fungi of the genus Pleurotus belong to the Basidiomycetes class, order Agaricales, family Tricholomataceae. This genus is distinguished by presenting fruiting bodies with concentric stems in the form of oyster shells, with joined blades. In the blades, there are basidia where the resultant basidiospores are formed by meiosis (Alexopoulos and Mims 1985).

The genus Pleurotus is a cosmopolitan group with mushrooms of a high nutritional value, therapeutic properties, and several environmental and biotechnological applications (Cohen et al., 2002). Pleurotus fruiting bodies are edible, have a pleasant odour, and contain carbohydrates, proteins, vitamins, mineral salts and lipids, but not cholesterol. Furthermore, they have medicinal properties (Chang et al., 1981). These fungi are also able to secrete enzymes and metabolites that depolymerize hemicellulose and cellulose, besides promoting lignin fragmentation (Kirk and
Cullen 1998). After cellulose, lignin is the most abundant organic material on earth, making up $20-30 \%$ of the dry weight of wood (Abdel-Raheem and Shearer 2002).

Pleurotus species have been recognized to produce enzymes such as manganese peroxidase (MnP) and laccase (Lcc) (Kamitsuji et al., 2004). Laccase is an oxidoreductase able to catalyse the oxidation of various aromatic compounds (particularly phenol) with the concomitant reduction of oxygen to water (Valeriano et al., 2009).

The interest in the study of ligninolytic enzymes such as Lcc and MnP - has grown due to their potential use in biotechnological processes. These phenol oxidases may be employed to treat effluents in the textile, paper and pulp industries, to biobleaching cellulose pulp and during the in vivo biodelignification of wood chips, to clarify wines and juices, as well as in polymerization reactions. What is more, they can also promote the blanching of fabrics (jeans), with reduced loss of resistance (Camassola and Dillon 2009, Gomes et al., 2009, Machado and Matheus 2006, Munari et 
al., 2008), but the most promising applications are in the bioremediation of soils that contain toxic substances ( $\mathrm{Wu}$ et al. 2008) and in the biological pre-treatment of biomass to produce biofuels (Camassola and Dillon 2009).

Since there may have been variability in phenol oxidase secretion by Pleurotus spp., this work evaluated different genotypes of Pleurotus isolated from basidiocarpi for Lcc and MnP secretion, using a sawdust-based substrate (Pinus spp.) in solid-state fermentation. These experiments target the use of Lcc and MnP in future processes of soil bioremediation and biological pre-treatment of biomass.

\section{Materials and Methods}

\section{Macrofungi}

Ten fungal strains of Pleurotus spp. belonging to the collection of microorganisms of the Enzymes and Biomass Laboratory, Institute of Biotechnology, University of Caxias do Sul, Rio Grande do Sul, Brazil, were used. The strains used are listed in Table 1. These strains were initially isolated from commercial strains.

\section{Cultivation media isolation medium, maintenance and inoculum}

The medium used for isolation, maintenance and preparation of inoculum contained $2 \%(\mathrm{w} / \mathrm{v})$ Pinus sp. sawdust, ground and swollen, $2 \%(\mathrm{w} / \mathrm{v})$ ground wheat bran, $0.2 \%(\mathrm{w} / \mathrm{v})$ calcium carbonate, and $2 \%(\mathrm{w} / \mathrm{v})$ agar. This medium was autoclaved at $120^{\circ} \mathrm{C}$ for $1 \mathrm{~min}$

The medium used for cultivation was prepared using 94\% (w/w) Pinus spp. sawdust, 5\% (w/w) wheat bran and $1 \%(\mathrm{w} / \mathrm{w})$ calcium carbonate. This medium was supplemented with $100 \mathrm{mg} . \mathrm{L}^{-1} \quad\left(\mathrm{NH}_{4}\right)_{2} \mathrm{SO}_{4}, \quad 0.1 \quad \mathrm{mg} . \mathrm{L}^{-1}$ $\mathrm{MnSO}_{4} \cdot \mathrm{H}_{2} \mathrm{O}$, and $0.1 \mathrm{mg} \cdot \mathrm{L}^{-1} \mathrm{CuSO}_{4} \cdot \mathrm{H}_{2} \mathrm{O}$. Water was added to the medium until $66 \%$ humidity was achieved. The medium was subsequently homogenized. Solid-state fermentation was carried out in $17.8 \times 13-\mathrm{cm}$ polypropylene bags containing $35 \mathrm{~g}$ of humid medium, which were sterilized at $120{ }^{\circ} \mathrm{C}$ for $2 \mathrm{~h}$. These recipients were called microfermentors.

\section{Cultivation}

In order to inoculate the solid-state fermentation, 1-cm-radius disks were taken from cultures grown in Petri dishes with the inoculum medium for 7 days at $25 \pm 1{ }^{\circ} \mathrm{C}$. For mycelial development, the cultures were kept in a dark environment at $25 \pm 1.5^{\circ} \mathrm{C}$ up to 32 days.

\section{Sampling and preparation of the total extracted proteins}

The full content of the microfermentors was used to extract the enzymatic broth. After homogenization, the content was mixed with $7 \mathrm{mLof}$ distilled water at $4{ }^{\circ} \mathrm{C}$, in 250-mL Erlenmeyer flasks. The flasks were shaken at $200 \mathrm{rpm}$ for $3 \mathrm{~min}$ The solids were removed by filtration
Table 1 - Pleurotus strains used in screening.

\begin{tabular}{lc}
\hline Strain & Species \\
\hline IB01 & P. sajor-caju \\
IB02 & P. cytrinopileatus \\
IB03 & P. cytrinopileatus \\
IB04 & P. ostreatus \\
IB05 & P. salmoneo-stramineus \\
IB06 & P. sajor-caju \\
IB07 & P. cytrinopileatus \\
IB09 & P. sajor-caju \\
IB11 & P. salmoneo-stramineus \\
IB17 & P. ostreatus \\
\hline
\end{tabular}

and the filtrates were centrifuged at $4000 \mathrm{~g}$, at $4{ }^{\circ} \mathrm{C}$, for 3 min The supernatant was used for the enzymatic dosages; four samples (microfermentors containing $35 \mathrm{~g}$ of humid medium) were collected on days 4, 8, 12, 16, 20, 24, 28 and 32.

\section{Enzymatic dosages}

The enzymatic activities were expressed as international units per gram of dry culture (mass) $\left(\mathrm{U} \mathrm{gdm}^{-1}\right)$. One unit was considered as the quantity $(\mu \mathrm{mol})$ of product released per minute $\left(\mathrm{IU}=\mu \mathrm{mol} \mathrm{min}^{-1}\right)$. Appropriate dilutions of the samples were done when necessary. The dry mass was obtained by carrying out the drying at $105^{\circ} \mathrm{C}$ for $24 \mathrm{~h}$ an aliquot of the culture medium.

The stock solutions of $\mathrm{H}_{2} \mathrm{O}_{2}$ were standardized under UV using the molar extinction coefficient $\varepsilon_{230}=81 \mathrm{M}^{-1} \mathrm{~cm}^{-1}$ against distilled water blank treated with catalase. This solution was used for determination of MnP.

The determination of MnP activity was performed following the method proposed by Kuwahara et al. (1984).

The determination of Lcc activity was performed following the method proposed by Wolfenden and Wilson (1982), using ABTS as substrate.

The enzymatic activities are expressed as units per gram of dry mass $\left(\mathrm{U} \mathrm{gdm}^{-1}\right)$.

\section{Protein determination}

Protein concentration was determined using the method of Bradford (1976). A minimum of four replicates was carried out for each of these protein assays.

\section{Zymograms}

SDS-polyacrylamide gel electrophoresis (PAGE) was performed as described by Laemmli (1970). After electrophoresis, the gel was stained with Coomassie Blue R dye in ethanol-acetic acid-water solution (5:1:4, by volume) for 2 minand destained in the same solution without dye. The sample buffer was prepared without addition of $\beta$-mercaptoethanol and the sample was not heated before running. 
For the staining of laccase activity, SDS was removed by washing the gel at room temperature in Solution A (sodium acetate buffer, $\mathrm{pH}$ 5.0, containing isopropanol 25\%) for 1 minand in Solution B (sodium acetate buffer, $\mathrm{pH}$ 5.0) for 1 min respectively. The gel was then transferred onto a glass plate and a layer of ABTS-agar $(0.02 \mathrm{~g}$ of ABTS, $0.4 \mathrm{~g}$ of agar, $40 \mathrm{~mL}$ of water; heated to dissolve agar) was placed on the gel. These layers were incubated for about $1 \mathrm{~min}$ at $25^{\circ} \mathrm{C}$, until the green bands' appearance.

\section{Results}

The results showed Lcc and MnP activities in all Pleurotus spp. strains studied. Variations between them were also observed (Figures 1 and 2). The greatest of Lcc activity, using ABTS as substrate, was found in a $P$. salmoneo-stramineus strain (IB11) (Figure 1D). As seen in Figure 1, strain IB11 showed an activity of $741 \pm 245 \mathrm{U}$ $\mathrm{gdm}^{-1}$ of culture on the $32^{\text {nd }}$ day of cultivation, while the others had mean activities ranging from 324 to $459 \mathrm{U} \mathrm{gdm}^{-1}$ of culture. However, strain IB09 (P. sajor-caju) showed an activity of $347 \mathrm{U} \mathrm{gdm}^{-1}$ of culture already on the eighth day, and also a higher productivity, $43 \pm 6 \mathrm{U} \mathrm{gdm}^{-1}$ day $^{-1}$, than

strain IB11. Although IB11 presented a higher activity peak, it occurred after 32 days, and the productivity was $23 \pm 7 \mathrm{U} \mathrm{gdm}^{-1}$ day $^{-1}$.

The evaluations of MnP (Figure 2) showed greater activity on the $12^{\text {th }}$ day for strains IB11 $(P$. salmoneostramineus - Figure 2D), $5999 \pm 1078 \mathrm{U} \mathrm{gdm}^{-1}$; IB05 $(P$. salmoneo-stramineus - Figure 2D), $5332 \pm 357 \mathrm{U} \mathrm{gdm}^{-1}$; IB09 (P. sajor-caju - Figure 2A), $5163 \pm 739 \mathrm{U} \mathrm{gdm}^{-1}$; and IB01 (P. sajor-caju - Figure 2A), $4701 \pm 652 \mathrm{U} \mathrm{gdm}^{-1}$. For strain IB06 (P. sajor-caju- Figure 2A), the activity peak occurred on the $8^{\text {th }}$ day of cultivation, reaching values of $2817 \pm 685 \mathrm{U} \mathrm{gdm}^{-1}$. Strains IB02 and IB07, both of $P$. cytrinopileatus, presented their greatest activity between the $8^{\text {th }}$ and $12^{\text {th }}$ days, keeping stability afterwards.

Besides the observed discrepancies in the enzymatic activities of different strains, distinct band patterns in SDS-PAGE of total proteins and laccases activities were also noted (Figures 3 and 4). Although some strains have been classified as same species, it can be observed in the total proteins SDS-PAGE (Figure 3) that they presented diverse band patterns, as it could be detected in P. sajor-caju IB01, IB06 and IB09 strains. The band pattern observed in
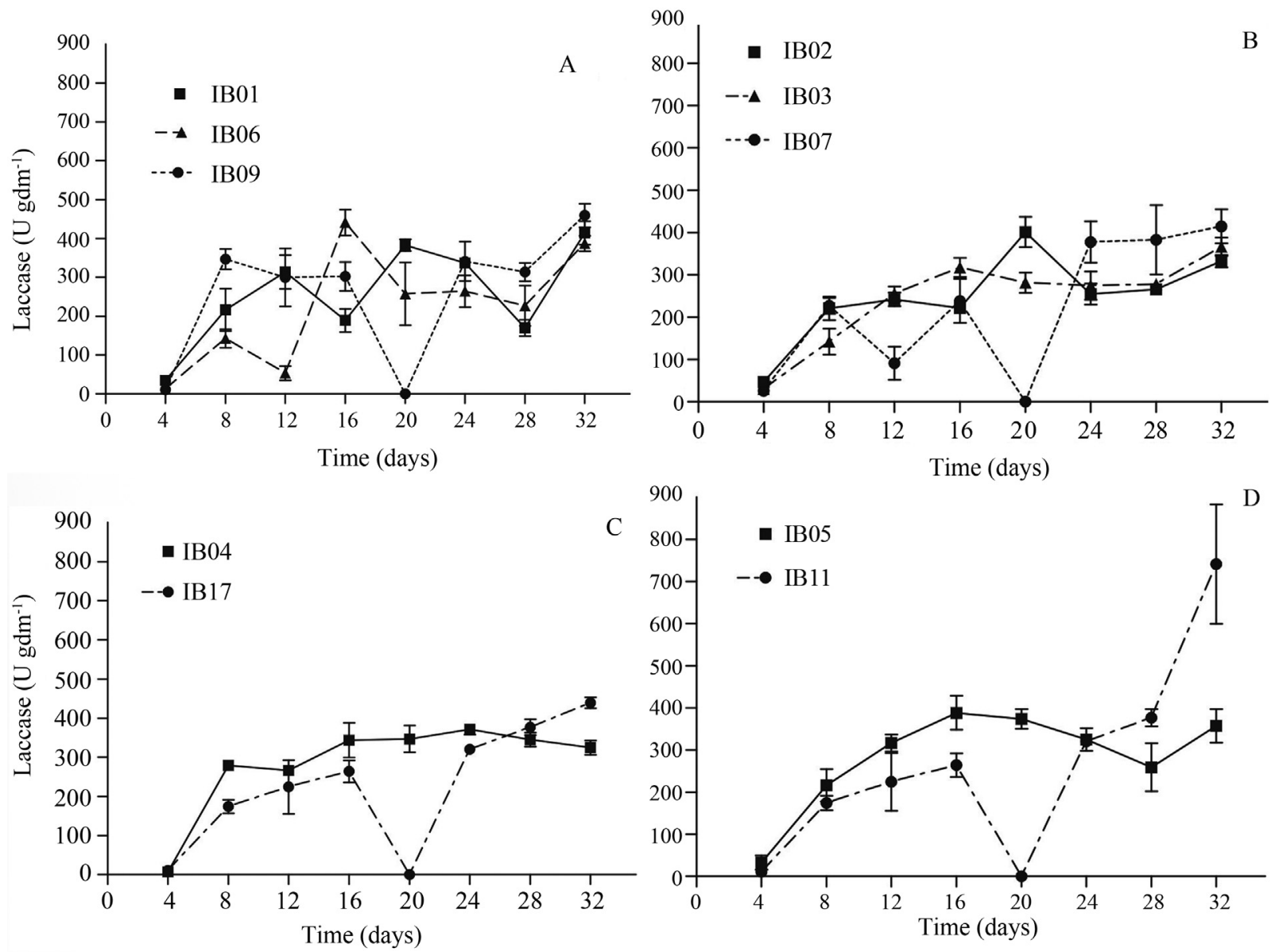

Figure 1 - Laccase activity during solid-state cultivation of strains of Pleurotus sajor-caju (1A), Pleurotus cytrinopileatus (1B), Pleurotus ostreatus (1C) and Pleurotus salmoneo-stramineus (1D). 

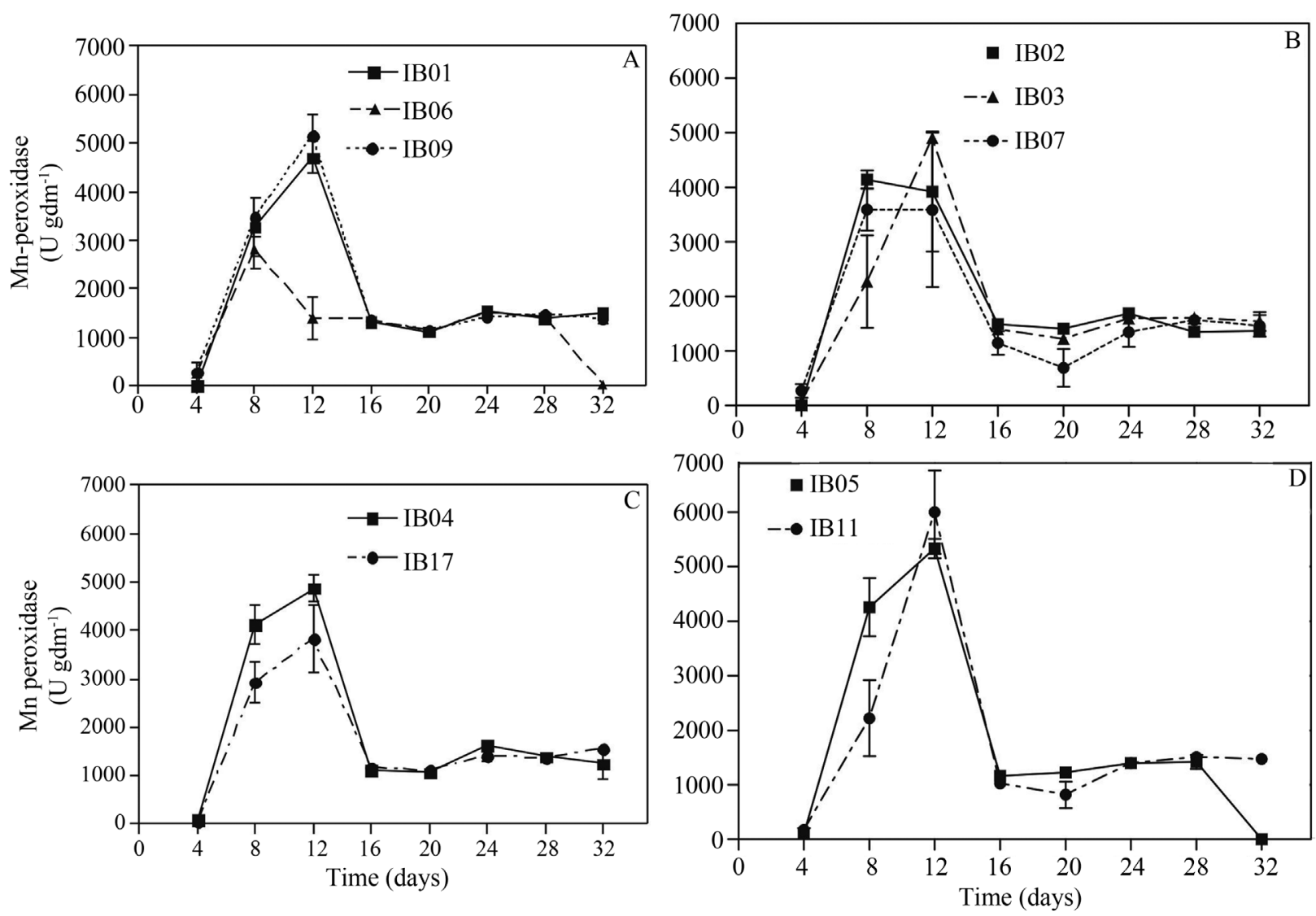

Figure 2 - Manganese-peroxidase activity during solid-state cultivation of strains of Pleurotus sajor-caju (2A), Pleurotus cytrinopileatus (2B), Pleurotus ostreatus (2C) and Pleurotus salmoneo-stramineus (2D).

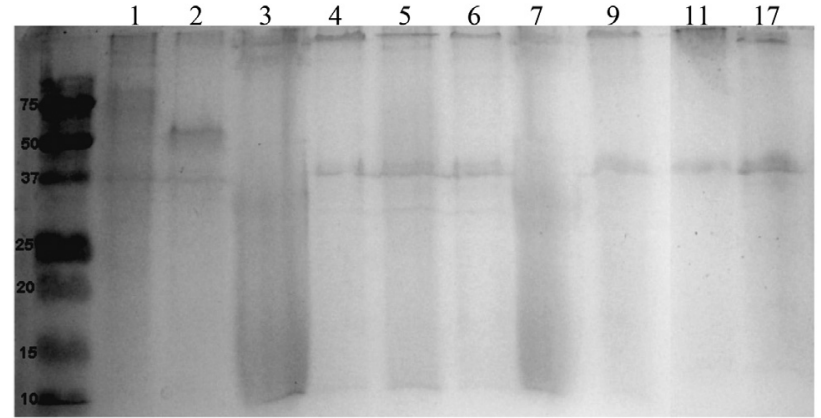

Figure 3 - SDS-PAGE of total extracted proteins stained with Coomassie Blue R dye found in different species of Pleurotus. Were used samples obtained at peak of each strain. M: Standard protein molecular weight in kilodaltons. Numbers specify the strains. IB01 - P. sajor-caju, IB02 - P. cytrinopileatus, IB03 - P. cytrinopileatus, IB04 - P. ostreatus, IB05 - P. salmoneo-stramineus, IB06 - P. sajor-caju, IB07 - P. cytrinopileatus, IB09 - P. sajor-caju, IB11 - P. salmoneo-stramineus and IB17 - P. ostreatus.

the IB01 strain differs completely from the IB06 and IB09 strains. The presence of glycosylated proteins - diffuse band patterns- and proteins weighing more than $37 \mathrm{kDa}$ can be noted in the result for IB01strain. The strain IB06 presented a band about $34 \mathrm{kDa}$, yet this outcome was not observed in IB09.
Differences in band patterns were also observed among $P$. cytrinopileatus strains, where IB03 and IB07 presented similar patterns and diffused bands, which indicates the presence of glycosylated proteins. Yet IB02 showed distinctive bands, in comparison to other $P$. cytrinopileatus strains and Pleurotus species here analyzed.

Similar band patterns were observed when comparing the results for the morphologically distinctive $P$. ostreatus IB04 and IB17 strains, which have brown and grey colours, respectively. Two bands with similar molecular mass could be noticed $(250 \mathrm{kDa}$ e $37 \mathrm{kDa})$ amongst $P$. salmoneostramineus strains. However, other parallel bands (180 kDa e $33 \mathrm{kDa}$ ) were only observed in IB05 strains. Moreover, when observing the zymogram for total proteins, a higher similarity can often be noticed among strains from different species than among those that are part of same species (Figure 4).

Laccase activity and the corroboration of their glycoproteic nature can be seen in Figure 4. A greater pattern of diffused bands can be observed in IB01, whereas other $P$. sajor-caju strains here analysed presented bands with equal molecular mass of $57.5 \mathrm{kDa}$. Yet, $P$. cytrinopileatus IB03 and IB07 strains presented two bands for laccases (37.5 e $42 \mathrm{kDa}$ ), as well as equal band pattern in the total proteins gel, which suggests isoenzyme presence. 


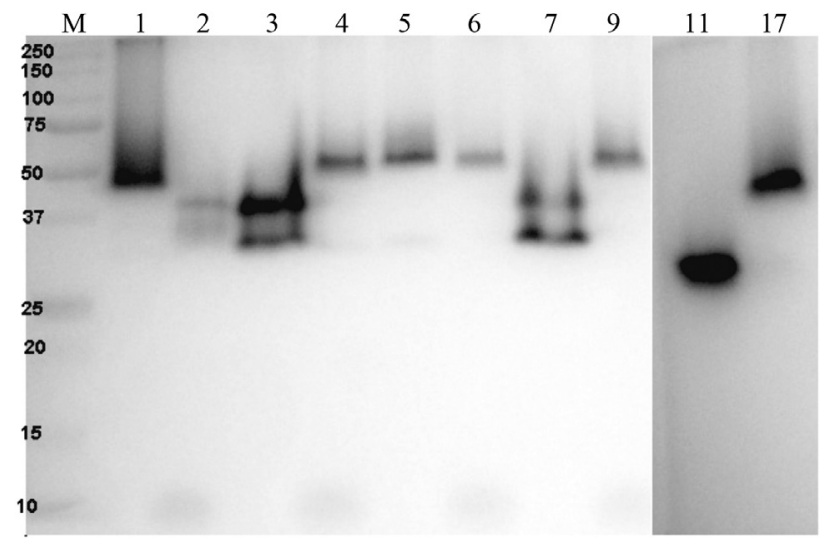

Figure 4 - Laccase identification in different species of Pleurotus. Proteins were separated on a $12 \%$ polyacrylamide gel electrophoresis. Were used samples obtained at peak of each strain. M: Standard protein molecular weight in kilodaltons. Numbers specify the strains. IB01 - P. sajorcaju, IB02 - P. cytrinopileatus, IB03 - P. cytrinopileatus, IB04 - P. ostreatus, IB05 - P. salmoneo-stramineus, IB06 - P. sajor-caju, IB07 - $P$. cytrinopileatus, IB09 - P. sajor-caju, IB11 - P. salmoneo-stramineus and IB17 - P. ostreatus.

The strain IB02 presented diffused bands with similar molecular masses obtained for $P$. cytrinopileatus IB03 and IB07, but different total proteins pattern. Distinctive molecular masses were observed in laccase band activity, regarding to P. salmoneo-stramineus strains. In the case of strain IB05, laccase presented average molecular mass of $60 \mathrm{kDa}$, while IB11had an average result of $30 \mathrm{kDa} . P$. ostreatus IB04 and IB17 strains presented molecular masses of $53.7 \mathrm{kDa}$ and $51.4 \mathrm{kDa}$, respectively.

Enzymatic specific activities obtained at peak of each sample are presented in Table 2. Laccases specific activities had values below $3 \mathrm{U}$ per $\mathrm{mg}$ of protein present in the extract. MnP presented the greater specific activity $\left(31 \mathrm{U} \mathrm{mg}^{-1}\right)$ in strain IB04.

\section{Discussion}

As observed by Stajic et al. (2004), the results showed variations in the activity of extracellular enzymes between the different species of Pleurotus, and also between strains of same species. As seen through this work, there is a potential to produce Lcc and $\mathrm{MnP}$ from strains IB11 and IB09. Although the substrates and methodologies of enzymatic activity analysis are not the same, it can be seen in Table 3 that the values for this study are higher than those shown before.

Lcc activities using ABTS as a substrate were similar to those observed by Silva (2004) (19) for P. sajor-caju, in which activities of $334 \pm 148 \mathrm{U} \mathrm{gdm}^{-1}$ and $949 \pm 164 \mathrm{U}$ $\mathrm{gdm}^{-1}$ were obtained after 15 and 30 days of cultivation, respectively, in a medium supplemented with the same salts used in this study.

High activities obtained may be related to the type of medium used in the growth of Pleurotus strains. Apart from
Table 2 - Enzymatic specific activities obtained at peak of each sample in solid-state cultivation of various Pleurotus species and strains.

\begin{tabular}{lcc}
\hline Strain & $\mathrm{MnP}\left(\mathrm{U} \mathrm{mg}^{-1}\right)$ & Laccase $\left(\mathrm{U} \mathrm{mg}^{-1}\right)$ \\
\hline IB01 & 25.17 & 1.16 \\
IB02 & 27.03 & 2.62 \\
IB03 & 18.33 & 1.37 \\
IB04 & 31.32 & 2.39 \\
IB05 & 27.69 & 2.02 \\
IB06 & 12.72 & 2.65 \\
IB07 & 12.79 & 1.48 \\
IB09 & 24.29 & 2.16 \\
IB11 & 24.71 & 1.81 \\
IB17 & 15.61 & 1.79 \\
\hline
\end{tabular}

being rich in salts, the medium also contained lignocellulose, which is essential in the studied enzyme induction.

Elisashvili et al. (2006) proved that the presence of a lignocellulosic substrate is mandatory for $\mathrm{MnP}$ production by $P$. dryinus IBB 903 , since there was no enzyme production when the fungus was cultivated in a synthetic medium with different carbon sources.

Besides the differences observed in the enzymatic production, it is important to note that different band patterns were obtained in same species strains, while similar patterns were found in diverse species strains, for the SDSPAGE of total extracted proteins as well as for the laccase activity gel assay.

The observation of two activity bands in some strains suggests the presence of isoenzymes. Such occurrence has already been observed in laccases of other Pleurotus species. Munõz et al. (1997) verified that Pleurotus eryngii produces two laccase isoenzymes, with molecular masses of $65 \mathrm{kDa}$ and $61 \mathrm{kDa}$, respectively. Both isoenzymes are stable at high $\mathrm{pH}$, retaining 60 to $70 \%$ activity after $24 \mathrm{~h}$ from $\mathrm{pH} 8$ to 12 . Mansur et al. (2003) verified that $P$. ostreatus strain V-184 synthesize four laccase isozymes (LCC1, LCC2, LCC3 and LCC4). LCC1 and LCC2 have average molecular masses of 60 and $65 \mathrm{kDa}$, and exhibited the same $\mathrm{pI}$ value (3.0). Their $\mathrm{N}$ termini were sequenced, revealing the same amino acid sequence and homology with laccases from other microorganisms. Laccases LCC3 and LCC4 were characterized by SDS-PAGE, estimating their molecular masses in 80 and $82 \mathrm{kDa}$, respectively. By native isoelectrofocusing, their $\mathrm{pI}$ values were 4.7 and 4.5 , respectively.

The activity gel assay indicated that most laccases are glycosylated. Glycosylation is important for solubility of enzymes (Barbaric et al., 1984), their catalytic activity, thickening properties and thermostability (Wang et al., 1996) Strains IB03 and IB07 have two clearly defined bands in the activity gel, but the lower specific activities, 
Table 3 - Comparison of enzymes production from different Pleurotus species grown on lignocellulosic materials.

\begin{tabular}{|c|c|c|c|c|}
\hline \multirow[t]{2}{*}{ Organism } & \multirow[t]{2}{*}{ Substrate } & \multicolumn{2}{|c|}{$\begin{array}{l}\text { Enzyme activities }\left(\mathrm{U} \mathrm{gdm}^{-1}\right) \text { Substrate used } \\
\text { to enzymatic assay }\end{array}$} & \multirow[t]{2}{*}{ Reference } \\
\hline & & Laccase & $\mathrm{MnP}$ & \\
\hline P. salmoneo-stramineus IB11 & $\begin{array}{l}\text { Pinus spp. sawdust, wheat bran, calcium } \\
\text { carbonate }\end{array}$ & $741.16^{(1)}$ & $5,999.25^{(3)}$ & This work \\
\hline P. sajor-caju IB09 & $\begin{array}{l}\text { Pinus spp. sawdust, wheat bran, calcium } \\
\text { carbonate }\end{array}$ & $346.87^{(1)}$ & $5,163.12^{(3)}$ & This work \\
\hline P. salmoneo-stramineus IB05 & $\begin{array}{c}\text { Pinus spp. sawdust, wheat bran, calcium } \\
\text { carbonate }\end{array}$ & $388.3^{(1)} 0$ & $5,332.36^{(3)}$ & This work \\
\hline P. dryinus IBB 903 & Tree leaves (Fagus sylvatica) & $4.00^{(1)}$ & $4.00^{(3)}$ & (Elisashvili et al., 2008) \\
\hline P. ostreatus IBB & Tree leaves (Fagus sylvatica) & $1.75^{(1)}$ & $1.75^{(3)}$ & (Elisashvili et al., 2008) \\
\hline P. ostreatus IBB & Tree leaves (Fagus sylvatica) & $3.50^{(1)}$ & $3.50^{(3)}$ & (Elisashvili et al., 2008) \\
\hline P. ostreatus 2175 & Tree leaves (Fagus sylvatica) & $3.75^{(1)}$ & $3.75^{(3)}$ & (Elisashvili et al., 2008) \\
\hline P. ostreatus 2191 & Tree leaves (Fagus sylvatica) & $3.50^{(1)}$ & $3.50^{(3)}$ & (Elisashvili et al., 2008) \\
\hline P. tuberregium IBB 624 & Wheat straw & $5.00^{(1)}$ & $0.53^{(3)}$ & (Elisashvili et al., 2008) \\
\hline P. dryinus IBB 903 & Wheat straw & $3.25^{(1)}$ & $1.43^{(3)}$ & (Elisashvili et al., 2008) \\
\hline P. ostreatus IBB & Wheat straw & $1.75^{(1)}$ & $1.48^{(3)}$ & (Elisashvili et al., 2008) \\
\hline P. ostreatus IBB & Wheat straw & $2.50^{(1)}$ & $0.28^{(3)}$ & (Elisashvili et al., 2008) \\
\hline P. ostreatus 2175 & Wheat straw & $3.00^{(1)}$ & $1.88^{(3)}$ & (Elisashvili et al., 2008) \\
\hline P. ostreatus 2191 & Wheat straw & $4.25^{(1)}$ & $0.03^{(3)}$ & (Elisashvili et al., 2008) \\
\hline P. tuberregium IBB 624 & Wheat straw & $2.50^{(1)}$ & $0,55^{(3)}$ & (Elisashvili et al., 2008) \\
\hline P. cornicopiae 32 & Grapevine sawdust & $5.58^{(2)}$ & - & (Stajic et al., 2004) \\
\hline P. cystidiosus 95 & Grapevine sawdust & $3.61^{(2)}$ & - & (Stajic et al., 2004) \\
\hline P. cytrinopileatus 602 & Grapevine sawdust & $0.91^{(2)}$ & - & (Stajic et al., 2004) \\
\hline P. djamor 485 & Grapevine sawdust & $2.19^{(2)}$ & - & (Stajic et al., 2004) \\
\hline P. eryngii 193 & Grapevine sawdust & $1.09^{(2)}$ & - & (Stajic et al., 2004) \\
\hline P. eryngii 555 & Grapevine sawdust & $0.17^{(2)}$ & - & (Stajic et al., 2004) \\
\hline P. ostreatus 207 & Grapevine sawdust & $3.49^{(2)}$ & - & (Stajic et al., 2004) \\
\hline P. ostreatus var. florida 393 & Grapevine sawdust & $3.14^{(2)}$ & - & (Stajic et al., 2004) \\
\hline P. pulmonarius 509 & Grapevine sawdust & $0.77^{(2)}$ & - & (Stajic et al., 2004) \\
\hline P. salignus 328 & Grapevine sawdust & $0.26^{(2)}$ & - & (Stajic et al., 2004) \\
\hline P. salmoneostramineus 77 & Grapevine sawdust & $1.13^{(2)}$ & - & (Stajic et al., 2004) \\
\hline P. smithii 138 & Grapevine sawdust & $1.38^{(2)}$ & - & (Stajic et al., 2004) \\
\hline
\end{tabular}

${ }^{(1)}$ ABTS. ${ }^{(2)}$ Syringaldazine. ${ }^{(3)}$ Phenol red.

while IB02 and IB06 strains presented the higher specific activities, but only discreet activity bands.

Laccases produced by IB02 e IB06 may have lost activity during electrophoresis, where a separating gel buffer (pH 8.8) was used. Yet, laccases secreted by IB03and IB07, which presented more diffused bands and subsequent indication of glycosylation, showed higher intensity bands. Moreover, the laccase isozymes secreted by IB01 with the lower specific activity presented the more intense band activity, suggesting that the glycosylations may have protected these enzymes during the electrophoretic run, or for any other reason, this enzyme can keep its activity, even in adverse conditions, like during the electrophoresis.
It is important to observe that laccases bands were not detected in the total proteins gel, which indicates their small proportion in relation to the total protein amount produced by the Pleurotus strains.

\section{Conclusion}

The results obtained in the present study show the importance of further research on the lignocellulolytic enzymes present in different species and strains of Pleurotus. Thus, it will be possible to select more promising strains for future biotechnological applications, and obtain valueadded products from mushrooms, such as phenol oxidase enzymes. Further studies on the role of laccases in humi- 
cation processes and in the transformation of xenobiotics, such as pesticides, should be investigated.

\section{References}

Abdel-Raheem A, Shearer CA (2002) Extracellular enzyme production by freshwater ascomycetes. Fungal Divers 11:1-19.

Alexopoulos CJ, Mims CW (1985) Introducción a la Micología. Omega, Barcelona, 638 pp.

Barbaric S, Mrsa V, Ries B, Mildner P (1984) Role of the carbohydrate part of yeast acid phosphatase. Arch Biochem Biophys 234:567-575.

Bradford MM (1976) Rapid and sensitive method for the quantitation of microgram quantities of protein utilizing the principle of protein-dye binding. Biochem 72:248-254.

Camassola M, Dillon AJP (2009) Biological pretreatment of sugar cane bagasse for the production of cellulases and xylanases by Penicillium echinulatum. Ind Crops Prod 29:642-647.

Chang ST, Lau OW, Cho KY (1981) The cultivation and nutritional value of Pleurotus sajor-caju. Appl Microbiol Biotechnol 12:58-62.

Cohen R, Persky L, Hadar Y (2002) Biotechnological applications and potential of wood-degrading mushrooms of the genus Pleurotus. Appl Microbiol Biotechnol 58:582-594.

Elisashvili V, Penninckx M, Kachlishvili E, Asatiani M, Kvesitadze G (2006) Use of Pleurotus dryinus for lignocellulolytic enzymes production in submerged fermentation of mandarin peels and tree leaves. Enzyme Microb Technol 38:998-1004.

Elisashvili V, Penninckx M, Kachlishvili E, Tsiklauri N, Metreveli E, Kharziani T, Kvesitadze G (2008) Lentinus edodes and Pleurotus species lignocellulolytic enzymes activity in submerged and solid-state fermentation of lignocellulosic wastes of different composition. Bioresour Technol 99:457-462.

Gomes E, Aguiar AP, Carvalho CC, Bonfá MRB, Silva R, Boscolo M (2009) Ligninases production by Basidiomycetes strains on lignocellulosic agricultural residues and their application in the decolorization of synthetic dyes. Braz J Microbiol 40:31-39.

Kamitsuji H, Honda Y, Watanabe T, Kuwahara M (2004) Direct oxidation of polymeric substrates by multifunctional manganese peroxidase isoenzyme from Pleurotus ostreatus without redox mediators. Appl Microbiol Biotechnol 65:287-294.

Kirk TK, Cullen D (1998) Enzymology and molecular genetics of wood degradation by white-rot fungi. In: Young RA, Akhtar M (eds) Environmentally Friendly Technologies for the Pulp and Paper Industry. Wiley, New York, pp 273-307.
Kuwahara M, Glenn JK, Morgan MA, Gold MH (1984) Separation and characterization of two extracellular $\mathrm{H}_{2} \mathrm{O}_{2}$ - Dependent oxidases from ligninolytic cultures of Phanerochaete chrysosporium. FEBS Lett 169:247-250.

Laemmli UK (1970) Cleavage of structural proteins during the assembly of the head of bacteriophage T4. Nature 227:680685.

Machado KMG, Matheus DR (2006) Biodegradation of remazol brilliant blue R by ligninolytic enzymatic complex produced by Pleurotus ostreatus. Braz J Microbiol 37:468-473.

Mansur M, Arias ME, Copa-Patinõ JL, Flärdh M, González AE (2003) The white-rot fungus Pleurotus ostreatus secretes laccase isozymes with different substrate specificities. Mycologia 95:1013-1020.

Munari FM, Gaio TA, Calloni R, Dillon AJP (2008) Decolorization of textile dyes by enzymatic extract and submerged cultures of Pleurotus sajor-caju. World J Microbiol Biotechnol 24:1383-1392.

Munõz C, Guillén F, Martínez AT, Martínez MJ (1997) Laccase isoenzymes of Pleurotus eryngii: Characterization, catalytic properties, and participation in activation of molecular oxygen and $\mathrm{Mn}^{2+}$ oxidation. Appl Environm Microbiol 63:2166-2174.

Silva SM (2004) Otimização das Condições de Cultivo Sólido de Pleurotus sajor-caju em Meio Constituído de Serragem de Pinus spp. MSc. Dissertation, Instituto de Biotecnologia, Caxias do Sul, Brasil, 89 pp.

Stajic M, Persky L, Cohen E, Hadar Y, Brceski I, Wasser SP, Nevo E (2004) Screening of laccase, manganese peroxidase, and versatile peroxidase activities of the genus Pleurotus in media with some raw plant materials as carbon sources. Appl Biochem Biotechnol 117:155-164.

Valeriano VS, Silva AMF, Santiago MF, Bara MTF, Garcia TA (2009) Production of laccase by Pynoporus sanguineus using 2,5 - Xylidine and ethanol. Braz J Microbiol 40:790-794.

Wang C, Eufemi M, Turano C, Giartosio A (1996) Influence of carbohydrate moiety on the stability of glycoproteins. Biochem 35:7299-7307.

Wolfenden RS, Wilson RL (1982) Radical-cations as reference chromogens in the kinetic studies of one-electron transfer reactions: Pulse radiolysis studies of 2,2'-azinobis-(3-ethylbenzthiazoline-6-sulphonate). J Chem Soc Perkin Trans 2:805-812.

Wu Y, Teng Y, Li Z, Liao X, Luo Y (2008) Potential role of polycyclic aromatic hydrocarbons (PAHs) oxidation by fungal laccase in the remediation of an aged contaminated soil. Soil Biol Biochem 40:789-796.

All the content of the journal, except where otherwise noted, is licensed under a Creative Commons License CC BY-NC. 